\title{
Effectiveness of Phosphorous Fertilizers in Wheat Crop Production in Pakistan
}

\author{
Aftab Jamal ${ }^{1 *}$ and Muhammad Fawad ${ }^{2}$ \\ ${ }^{1}$ Department of Soil and Environmental Sciences University of Agriculture Peshawar, Pakistan \\ ${ }^{2}$ Department of Weed Science University of Agriculture Peshawar, Pakistan \\ *aftabses98@gmail.com
}

Keywords: Wheat crop, Phosphorous, Pakistan

\begin{abstract}
Phosphorus (P) is that element of the periodic table, which is extensively found in nature and along with nitrogen and potassium represents the overall composition of plants and animal life. Phosphorus performed different metabolic activities in plants and is one of the key elements for the maturation of plants and boosting up the larger quantities. As it has a vital role in the metabolism and energy production reaction and can survive the unfavorable environmental effects so cause increase in yield. A research review was carried out on the effectiveness of $\mathrm{P}$ fertilizers for wheat crop production in Pakistan. Almost all of the researchers in all areas indicated that $\mathrm{P}$ fertilizers significantly improved the growth as well as yield parameters of wheat crop. But the optimum rate of $\mathrm{P}$ fertilizer at which highest yield recorded was different for each area, soil and environmental condition. Although these findings on $\mathrm{P}$ fertilization representing many capable results regarding to yield and yield components of wheat but still further research is strongly recommended to evaluate the dynamics of $\mathrm{P}$ in soil as well as the interaction effect of $\mathrm{P}$ with other micro and macro nutrients.
\end{abstract}

\section{Introduction}

Phosphorus has a vital role in the metabolism and energy production reaction and can survive the unfavourable environmental effects so cause an increase in yield [1]. Phosphorous has a dominant role in the physiological processes of living organisms particularly in plants [2].

Most of Pakistan soils are calcareous in nature, which are not only low in the parent material containing the phosphorus mineral but its alkaline nature further reduces its availability in soil. Most of the soils in Pakistan contain less than $10 \mathrm{mg} \mathrm{P}_{2} \mathrm{O}_{5} \mathrm{~kg}^{-1}$ soil [3]. Wheat occupied more than 36.3 of the total cropped area of Pakistan which is still below the average production of wheat as compared with developing countries [4]. The most important factor which increases wheat crop production is the supply of nutrients in an adequate amount [5]. J.M.T. Tariq et al. [6] also considered the adequate and proper supply of nutrients to wheat crop as key factor for optimum production.

Soils of Pakistan are alkaline in reaction and calcareous in nature that's why P fixation in these soils is a serious problem when $P$ fertilizers are added to the soil, the soil rapidly and tightly adsorbed large amount of $\mathrm{P}$ and this adsorbed $\mathrm{P}$ is not available to plants [7]. According to [8] $93 \%$ of Pakistani soils are deficient in available $\mathrm{P}$; the phosphorus fertilizer use can help to reduce the adverse effect of drought under rainfed conditions. P got dominant importance for crop production and importance is being given on the efficient use of $P$ fertilizers for sustainable crop production [9].

Even though tremendous amount of research have been conducted on phosphorus for the last many years, its behavior in the soil and availability to crops are still not fully understood. Therefore, continued evaluation of fertilizer effectiveness should be exercised through short and long term experimentation [10], and different methods of fertilizer application need to be assessed in depth for a more meaningful correlation with yield and plant uptake [11]. 


\section{Review of Literature}

\subsection{Availability of $P$ and soil conditions}

Even though the overall $\mathrm{P}$ content in soil is high (> 80\%), yet certain factors like adsorption, conversion of $\mathrm{P}$ into organic forms and precipitation of $\mathrm{P}$ restricts its availability for the plants. Iron and aluminium dominate the acidic soils, upon reaction with $\mathrm{P}$ they form either Fe phosphate or aluminium phosphate, and adsorption of $\mathrm{P}$ occurs to Fe oxides or aluminium oxides or also to humic substances, whereas in alkaline calcareous soils $\mathrm{P}$ reacts with $\mathrm{Ca}$ to form $\mathrm{Ca}-\mathrm{P}$. In many soils more than $50 \%$ of overall $\mathrm{P}$ is organic $\mathrm{P}$ (mostly Phytate) [12]. Plants take P from the soil solution in monovalent $\left(\mathrm{H}_{2} \mathrm{PO}_{4}\right)$ and divalent $\left(\mathrm{HPO}_{4}\right)$ orthophosphate anions forms, at a neutral $\mathrm{pH}$ each of them show almost $50 \%$ of the total $\mathrm{P}$. In acidic soil condition $\mathrm{pH} 4-6, \mathrm{H}_{2} \mathrm{PO}_{4}$ is dominant, however in alkaline soil $\mathrm{pH} 8 \mathrm{HPO}_{4}$ is $80 \%$ of overall $\mathrm{P}$ [13].

M. Amrani et al. [14] worked on P adsorption of arid and semiarid regions soils. Langmuir, Cooke, and Freundlich models were applied to determine $\mathrm{P}$ sorption. The results concluded that various soil solutions $\mathrm{P}$ are required for different soil series to obtain optimum yield. Soil $\mathrm{P}$ availability is influenced by many factors such as soil reactions, amount and form of $\mathrm{P}$ as well as soil type [15]. More P fertilization was suggested in high clay-calcareous soils by L.S. Tisdale et al. [10] because large quantities of clay will fix more P than soils with low clay content. Similarly [16] suggested that as the soil solution $\mathrm{P}$ increased, the adsorption also increased simultaneously, while working on 11 different soil series of rice. Moreover, it was also summarized that adsorption has a close relation with clay and free lime content of soil. The response of plants towards phosphatic fertilizers and the availability of $\mathrm{P}$ in soil solution concentration are greatly affected by $\mathrm{P}$ sorption capacity [17], and also have an adverse effect on the movement of $\mathrm{P}$ in soil [18].

\subsection{Impact of $P$ fertilizers on wheat growth and yield}

A tremendous amount of investigations were carried out on the effect of phosphorous fertilizers on different crops, however, the scope of this review is focused on the effect of phosphorous fertilizers on wheat crop production in Pakistan.

A. Rahim et al. [19] found that P and irrigation levels have a significant effect on wheat yield. $\mathrm{P}$ at the rate of $81 \mathrm{~kg} \mathrm{ha}^{-1}$ could result the maximum grain yield if an application is done through band placement rather than broadcast method. Proper irrigation at various levels of crop growth could result optimum yield and also increased $\mathrm{P}$ use efficiency. Adsorption isotherms are useful to calculate various $\mathrm{P}$ doses for crop requirements. [20] summarized the effect of nitrogen and phosphorous on wheat yield and concluded that both $\mathrm{N}$ and $\mathrm{P}$ affect the agronomic parameters of wheat crop. $\mathrm{N}$ and $\mathrm{P}_{2} \mathrm{O}_{5}$ at the rate of 120 and $90 \mathrm{~kg} \mathrm{ha}^{-1}$ could attribute the maximum yield under the agro-climatic conditions. Similarly, two experiments conducted during 2013 on Peshawar and Guliana soil series having diverse lime content 19 and 4\% respectively, and revealed that in Peshawar soil wheat yield increased by $76.5 \%$ at $45-135 \mathrm{~kg} \mathrm{P}_{2} \mathrm{O}_{5} \mathrm{ha}^{-1}$ as compared to Guliana soil where the maximum yield of $54.8 \%$ was obtained at $90 \mathrm{~kg} \mathrm{P}_{2} \mathrm{O}_{5} \mathrm{ha}^{-1}$. The study of the two soils revealed, that wheat yield showed the significant increase in Guliana than Peshawar soil series, and concluded that high lime soil (Peshawar soil) required more $\mathrm{P}\left(90-135 \mathrm{P}_{2} \mathrm{O}_{5} \mathrm{ha}^{-1}\right)$ than low lime soil (Guliana) 45 to $90 \mathrm{~kg} \mathrm{P}_{2} \mathrm{O}_{5}$ $\mathrm{ha}^{-1}[4]$.

Moreover, the result of two-year experiment revealed that agronomic parameters of wheat like plant height, number of grains spike ${ }^{-1}$, grain weight spike ${ }^{-1}$ and 1000 -grain weight significantly increased by the application of $180 \mathrm{~kg} \mathrm{~N}$ and $90 \mathrm{~kg} \mathrm{P}_{2} \mathrm{O}_{5} \mathrm{ha}^{-1}$ [21]. In another experiment [22] reported that significant increase in wheat biomass yield can be obtained with the application of $\mathrm{P}$ at 75 to $100 \mathrm{~kg} \mathrm{ha}^{-1}$. Similarly the result of another experiment conducted at Agricultural University Peshawar indicated that application of phosphorus at the rate of $100 \mathrm{~kg} \mathrm{ha}^{-1}$ through double band placement significantly $(\mathrm{P}<0.05)$ enhanced plant height, productive tillers $\mathrm{m}^{-2}$, grains spike $\mathrm{e}^{-1}, 1000$ grain weight, biological yield, grain yield, harvest index and agronomic phosphorus efficiency of wheat crop and reduced non-productive tillers $\mathrm{m}^{-2}$ compared with other treatments [23]. The significant effect of $\mathrm{P}$ as foliar spray was also reported by [24] however in wheat the soil treatment yields good results as compared with foliar spray. 
Moreover, an experiment conducted during 2005-2006 at Bahauddin Zakariya University, Multan, Pakistan revealed that application of 60 to $120 \mathrm{~kg} \mathrm{P} \mathrm{ha}^{-1}$ maximally improved the growth parameters as well as yield of wheat crop [25]. Another study was conducted on $\mathrm{P}$ application methods, broadcast $\left(0\right.$ and $\left.100 \mathrm{~kg} \mathrm{P}_{2} \mathrm{O}_{5} \mathrm{~kg} \mathrm{ha}^{-1}\right)$ and fertigation $\left(50,75\right.$ and $\left.100 \mathrm{~kg} \mathrm{P}_{2} \mathrm{O}_{5} \mathrm{ha}^{-1}\right)$ in calcareous soils varying in $\mathrm{CaCO}_{3}$ concentrations $\left(6,9\right.$ and $\left.13 \% \mathrm{CaCO}_{3}\right)$. According to this study, Phosphorus fertigation at $100 \mathrm{~kg} \mathrm{ha}^{-1}$ significantly enhanced the grain (4.4 tons ha $\left.{ }^{-1}\right)$ and biological yields (11.4 tons $\mathrm{ha}^{-1}$ ) as compared to control and broadcast at each level of $\mathrm{CaCO}_{3} \%$ [26]. The experiment conducted on Rasulpur soil series (Typic Camborthid) revealed that $0.2 \mathrm{mg} \mathrm{P} \mathrm{L}$ L $^{-1}$ soil solution as per Freundlich equation is sufficient to produce the maximum grain as well as straw yield; however $\mathrm{P}$ concentration in grain and straw was maximum at $0.5 \mathrm{mg} \mathrm{PL}^{-1}$ soil solution, and advocated that for obtaining $95 \%$ relative yield of wheat both the external and internal solution $\mathrm{P}$ requirement were found to be $0.172 \mathrm{mg} \mathrm{P} \mathrm{L}^{-1}$ and $0.276 \%$ respectively [27]. In recent research on Swabi soil revealed that $90 \mathrm{~kg} \mathrm{ha}^{-1} \mathrm{P}$ along with $6 \mathrm{tha}^{-1}$ poultry manure is sufficient for obtaining the optimum yield of wheat crop [28]. The result of two consecutive years experiment during 2000-2001 and 20012002 indicated that maximum wheat yield can be achieved by broadcast application of $\mathrm{P}$ at $114 \mathrm{~kg} \mathrm{ha}^{-1}$ by intra row drilling techniques, according to this study increase in economic yield may be due to better availability and uptake of phosphate fertilizer by drilling method [29]. The result of another study revealed that application of phosphorus at a higher rate could compensate the drastic effect of water stress and increased wheat yield. On overall performance, application of phosphorus at the rate of $120 \mathrm{~kg} \mathrm{ha}^{-1}$ showed better yield under water stress conditions as compared to other phosphorus levels [30].

Furthermore the result of a pot experiment conducted during Rabi season 2007 at Rawalpindi indicated that phosphorus application at the rate of $80 \mathrm{~kg} \mathrm{P} \mathrm{ha}^{-1}$ as single super phosphate (SSP) showed better results as compared to triple superphosphate (TSP), nitrophos (NP) and diammonium phosphate (DAP) on phosphorus deficient soil of Balkasr area of Tehsil Chakwal [31]. Similarly in another study conducted on growth and yield of wheat cultivar Bhakar-2002 at the Agronomic Research Area, University of Agriculture, Faisalabad, during Rabi 2006-2007 concluded that phosphorus source in the form of DAP at the rate of $90 \mathrm{~kg} \mathrm{ha}^{-1}$ should be applied to get maximum benefit from wheat crop [32]. Another experiment was conducted at D.I Khan Pakistan during 20042005 with the main aim to evaluate the response of wheat to P. According to this study Phosphorus application significantly increased the grain yield of wheat from $2920 \mathrm{~kg} \mathrm{ha}^{-1}$ in control to $3560 \mathrm{~kg}$ $\mathrm{ha}^{-1}$ in the treatments receiving $\mathrm{P}$ at $90 \mathrm{~kg} \mathrm{P}_{2} \mathrm{O}_{5} \mathrm{ha}^{-1}$ giving an increase of $22 \%$ over control, moreover the growth parameters like number of tillers, spikes, spike length and plant height of wheat were also significantly increased by P application [33]. Similarly, the result of the study performed by [34] suggested that wheat grain yield increased with increasing level of $\mathrm{P}$ over control. The maximum increase in wheat grain yield over control was recorded with $36 \mathrm{mg} \mathrm{kg}^{-1}$ soil. The result of a two years field study conducted at Vehari Pakistan during 2008-2009 and 2009-2010 concluded that application of $\mathrm{P}$ as single superphosphate (SSP) gave better results as compared to nitrophos (NP), diammonium phosphate (DAP), monoammonium phosphate (MAP) and triple superphosphate (TSP) on phosphorus deficient soil, according to this study the wheat growth parameters were significantly increased with $\mathrm{P}$ application however different $\mathrm{P}$ fertilizers have the same effect on wheat emergence [35].

\section{Conclusions}

From this review it was clearly concluded that $\mathrm{P}$ has great importance in wheat crop nutrition, however, the findings of different investigators at different areas were not clearly addressed the issue related to socioeconomic rather all of them were focused on the impact of $\mathrm{P}$ on wheat yield and yield components. Although these findings on $\mathrm{P}$ fertilization representing many capable results regarding to yield and yield components of wheat still further research is strongly recommended to evaluate the dynamics of $\mathrm{P}$ in the soil as well as the interaction effect of $\mathrm{P}$ with other micro and macronutrients. 


\section{Conflict of Interest}

The authors declare that there is no conflict of interest.

\section{References}

[1] M. Azink, L. Kajfez, A nine year fertilizer experiments in maize, Kmetystov. 39 (1983) 7-21.

[2] K. Mengel, E. A. Kirkby, Principles of Plant Nutrition. $5^{\text {th }}$ ed., Intl. Potash Inst., Bern Switzerland, 2000.

[3] K.S. Memon, H.K. Puno, R.L. Fox, Phosphate Sorption Approach for Determining Phosphorus Requirement of Wheat in Calcareous Soils. Fertilizer Res. 28 (1991) 67-72.

[4] A. Manzoor, Critical soil solution phosphorous concentration essential for plant growth in calcareous soil series, PhD Thesis, 2013.

[5] N.K. Fageria, V.C. Baligar, C.A. Jones, Growth and mineral nutrition of field crops, CRC Press, 1997.

[6] J.M.T. Tariq et al., Response of wheat to source, type and time of nitrogen application, Sarhad J. Agric. 23(4) (2007) 871-879.

[7] A. Jamal et al., Application of adsorption isotherms in evaluating the influence of humic acid and farmyard manure on phosphorous adsorption and desorption capacity of calcareous soil, World Scientific News. 107 (2018) 136-149.

[8] N. Ahmad, A. Jalil, Balanced fertilization through phosphate promotion at farm level: terminal report, 1992.

[9] I. Ryan, Efficient use of phosphate fertilizers for sustainable crop production in WANA, IMPHOS: Phosphate Newsletter. (2002) 2-5.

[10] L.S. Tisdale, et al., Soil Fertility and Fertilizers. Macmillan publishing campany, New York, Toronto, Oxford and Singapore, 2002, 633p.

[11] A. Mesfin, Nature and Management of Ethiopian Soils, Alemaya University of Agriculture, Ethiopia, 1998, 272p.

[12] L.D. Osborne, Z. Rengel, Growth and P uptake by wheat genotypes supplied with phytate as the only P source, Australian Journal of Agricultural Research. 53 (2002) 845-850.

[13] C.A. Black, Soil-plant relationships, New York, USA, John Wiley \& Sons, 1968, pp. 243-288.

[14] M. Amrani, D.G. Westfall, L. Moughli, Phosphate sorption in calcareous Moroccan soils as affected by soil properties, Communications in soil science and plant analysis. 30(9-10) (1999) 1299-1314.

[15] Z. Eylachew, Study on Phosphorus Status of Different Soil Types of Chercher Highland, S.E. Ethiopia, Ph.D. Dissertation, der Justus Universitat Grie Ben, 1987, 186 p.

[16] M. Aslam et al., Application of freundlich adsorption isotherm to determine phosphorus requirement of several rice soils, Int. J. Agri. Biol. 2(4) (2000) 286-288.

[17] Hoford and Mattingly, Phosphate adsorption and availability plant of phosphate, Plant and Soil. 44(2) (1976) 377-389.

[18] D.M. Mackay et al., A natural gradient experiment on solute transport in a sand aquifer: 1 . Approach and overview of plume movement, Water Resources Research. 22(13) (1986) 20172029. 
[19] A. Rahim, A.M. Ranjha, E.A. Waraich, Effect of phosphorus application and irrigation scheduling on wheat yield and phosphorus use efficiency, Soil \& Environ. 29(1) (2010) 15 22.

[20] P. Khan et al., Effect of different nitrogen and phosphorus ratios on the performance of wheat cultivar 'Khirman', Sarhad J. Agric. 24 (2008) 233-240.

[21] M.B. Khan et al., Effect of different phosphatic fertilizers on growth attributes of wheat (Triticum aestivum L.), Journal of American Science. 6(12) (2010) 1256-1262.

[22] N. Hussain, N. Hyder, N. Ahmad, Influence of phosphorus application on growth and yield components of wheat cultivar Punjab-96, Indus J. Plant Sci. 3(3) (2004) 276-279.

[23] S. Bashir et al., Response of wheat crop to phosphorus levels and application methods, Journal of Environment and Earth Science. 5(9) (2015) 151-155.

[24] Z. Jamal et al., Effect of soil and foliar application of different concentrations of NPK and foliar application of $\left(\mathrm{NH}_{4}\right)_{2} \mathrm{SO}_{4}$ on different yield parameters in wheat, J. Agron. 5(2) (2006) 251256.

[25] N.A.Z.I.M. Hussain, M.B. Khan, R.I.A.Z. Ahmad, Influence of phosphorus application and sowing time on performance of wheat in calcareous soils, Int. J. Agri. Biol. 10 (2008) 399-404.

[26] M.S. Memon et al., 2011. Effect of phosphorus fertigation in wheat on different soils varying in $\mathrm{CaCO} 3$ levels, Pak. J. Bot. 43(6) 2911-14.

[27] M. Sarfraz et al., External and internal phosphorus requirement of wheat in Bhalike soil series of Pakistan, Pakistan Journal of Botany. 40 (2009) 2031-2040.

[28] A. Jamal, M. Fawad, Application of different organic manures in optimizing optimum yield for wheat in calcareous soil, World News of Natural Sciences. 20 (2018) 23-30.

[29] M.A. Ali et al., Effect of phosphorus application methods on yield of wheat, Pak. J. Life Soc. sci. 2(2) (2004) 185-187.

[30] M.Z. Mumtaz et al., Effect of different phosphorus levels on growth and yield of wheat under water stress conditions, Journal of Environment and Earth Science. 4(19) (2014) 23-30.

[31] Q.U. Khan, M.J. Khan, S. Ullah, Comparison of different models for phosphate adsorption in salt inherent soil series of Dera Ismail Khan, Soil and Environment. 29(1) (2010) 11-14.

[32] M.A. Majeed et al., Effect of phosphorus fertilizer sources and rates on growth and yield of wheat (Triticum aestivum L.), Asian. J. Agric. Biol. 2 (2014) 14-19.

[33] R. Khan et al., Effect of phosphorus application on wheat and rice yield under wheat-rice system, Sarhad Journal of Agriculture. 23(4) (2007) 851.

[34] M.S. Zia et al., Fertility issues and fertilizer management in rice wheat system, Quarterly Sci. Ver. 5(4) (2000) 59-73.

[35] M. Ali et al., Comparative performance of wheat in response to different phosphatic fertilizers, International Journal of Research in Agriculture and Forestry. 2(6) (2015) 1-9. 